\title{
Bioactive compounds from an endophytic fungi Nigrospora aurantiaca
}

\author{
Safwan Safwan ${ }^{1,2}$, George Hsiao ${ }^{3,4}$, Tzong-Huei Lee $5^{5^{*}}$ and Ching-Kuo Lee ${ }^{1,6^{*}}$
}

\begin{abstract}
Background: Many groups of fungi live as an endophyte in plants. Both published and undiscovered bioactive compounds can be found in endophytic fungi. Various biological activities of bioactive compounds from endophytic fungi had been reported, including anti-inflammatory and anticancerous effects.

The chemical investigation of biologically active compounds from endophytic fungi Melaleuca leucadendra Linn. have not yet been stated.

Results: One new compound, namely nigaurdiol (1), along with five known compounds, xyloketal K (2), bostrycin (3), deoxybostrycin (4), xylanthraquinone (5), and ergosterol (6), were isolated from the Melaleuca leucadendra Linn. associated fungal strain Nigrospora aurantiaca ${ }^{\# T M U 062 . ~ T h e i r ~ c h e m i c a l ~ s t r u c t u r e s ~ w e r e ~ e l u c i d a t e d ~ b y ~ s p e c t r o s c o p i c ~}$ data and compared with literature. All isolated compounds were evaluated for inhibitory effect of NO production in LPS-activated microglial BV-2 cells.
\end{abstract}

Conclusions: Compound $\mathbf{6}$ exhibited considerable inhibitory effect on $\mathrm{NO}$ production with $\mathrm{IC}_{50}$ values of $7.2 \pm 1.4 \mu \mathrm{M}$ and the survival rate of the cells was $90.8 \pm 6.7 \%$ at the concentration of $10 \mu \mathrm{M}$.

Keywords: Nigrospora aurantiaca, Melaleuca leucadendra, Endophytes fungi, Nitric oxide production

\section{Background}

Endophytes are defined as microorganisms that spend at least parts of their life cycle inhabiting in its host plants without causing apparent harm to the host (Hardoim et al. 2015). Endophytic fungi is one of the potential resources for obtaining bioactive compounds because of its complex interaction with their host plants or other microorganisms within the host plants. Previous studies showed that many bioactive compounds produced by endophytic fungi exhibit antioxidant, anticancer, antiinflammatory, antimicrobial, and other biological activities (Kumari et al. 2018; Ukwatta et al. 2020). Some of the medicinal plants have been found to rear a number

\footnotetext{
${ }^{*}$ Correspondence: thlee1@ntu.edu.tw; cklee@tmu.edu.tw

${ }^{1}$ Clinical Drug Development of Herbal Medicine, College of Pharmacy,

Taipei Medical University, Taipei 11031, Taiwan

${ }^{5}$ Institute of Fisheries Science, National Taiwan University, Taipei 10617,

Taiwan

Full list of author information is available at the end of the article
}

of highly diversified endophytic fungi, which could even produce the same compounds as their host plants. For instance, ginkgolide B can be produced by both Fusarium oxysporum and its host plant Ginkgo biloba (Cui et al. 2012). Thus, many of the folk medicinal plants were chosen to screen the associated fungal strains with significant biological activities in the recent past.

Melaleuca leucadendra Linn. of the Myrtaceae family is distributed across Australia and Southeast Asia countries like Indonesia (Pujiarti et al. 2011). The leaves of this family are known to contain a high concentration of terpenes with varied quality and quantity (Keszei et al. 2008). As a folk medicine, M. leucadendra Linn. was reported to exhibit antioxidant, antiproliferative, and anticancer activities (Rini et al. 2012; Monzote et al. 2020). However, related researches of the endophytic fungi from $M$. leucadendra Linn. have not yet been reported. This study focuses on the bioactivity and chemical investigation of Nigrospora aurantiaca isolated from $M$. leucadendra Linn. 


\section{Results and discussion}

Through chemical investigation of the liquid and solid fermented products, one new compound together with five known compounds on $N$. aurantiaca (an endophytic fungi from $M$. leucadendra) were identified. By comparing with literature data, the well-known compounds were recognized as xyloketal K (2) (Sun et al. 2016), bostrycin (3) (Stevens et al. 1979; Chen et al. 2012), deoxybostrycin (4) (Chen et al. 2012; Wang et al. 2013), xylanthraquinone (5) (Sommart et al. 2008), and ergosterol (6) (Kawai et al. 2018).

Compound 1, a colorless oil, was determined to have a molecular formula of $\mathrm{C}_{11} \mathrm{H}_{18} \mathrm{O}_{2},\left([\mathrm{M}+\mathrm{H}]^{+} m / z\right.$ 183.1381, calcd 183.1380) by HRESIMS analysis and evidenced by ${ }^{13} \mathrm{C}$ NMR spectrum. The IR spectrum confirmed the presence of hydroxy and olefinic functionalities at 3334 and $1646 \mathrm{~cm}^{-1}$, respectively. The ${ }^{1} \mathrm{H}$ NMR data $\left(\mathrm{CD}_{3} \mathrm{OD}\right.$, $600 \mathrm{MHz})$ spectrum showed two methyl groups of $\delta_{\mathrm{H}}$ $1.67\left(3 \mathrm{H}, \mathrm{d}, J=6.2 \mathrm{~Hz}, \mathrm{H}_{3}-1\right)$ and $\delta_{\mathrm{H}} 1.77(3 \mathrm{H}, \mathrm{dd}, J=6.7$, $\left.1.2 \mathrm{~Hz}, \mathrm{H}_{3}-9\right)$; six methine signals at $\delta_{\mathrm{H}} 3.00(1 \mathrm{H}, \mathrm{dt}$, $J=7.0,7.0 \mathrm{~Hz}, \mathrm{H}-4), \delta_{\mathrm{H}} 5.43(1 \mathrm{H}, \mathrm{dd}, J=16.4,7.0 \mathrm{~Hz}$, $\mathrm{H}-3), \delta_{\mathrm{H}} 5.52(1 \mathrm{H}, \mathrm{dq}, J=16.4,6.2 \mathrm{~Hz}, \mathrm{H}-2), \delta_{\mathrm{H}} 5.70(1 \mathrm{H}$, $\mathrm{dq}, J=14.8,6.7 \mathrm{~Hz}, \mathrm{H}-8), \delta_{\mathrm{H}} 5.94(1 \mathrm{H}, \mathrm{d}, J=11.0 \mathrm{~Hz}$, $\mathrm{H}-6)$, and $\delta_{\mathrm{H}} 6.43(1 \mathrm{H}, \mathrm{ddq}, J=14.8,11.0,1.2 \mathrm{~Hz}, \mathrm{H}-7)$; and two oxygenated methylene signals at $\delta_{\mathrm{H}} 3.55$ and 3.63 (each $1 \mathrm{H}, \mathrm{dd}, J=10.7,7.0 \mathrm{~Hz}, \mathrm{H}_{2}-11$ ) and $\delta_{\mathrm{H}} 4.14$ and 4.18 (each $1 \mathrm{H}, \mathrm{d}, J=12.0 \mathrm{~Hz}, \mathrm{H}_{2}-10$ ). The DEPT ${ }^{13} \mathrm{C}$ NMR in combination with the ${ }^{13} \mathrm{C}$ NMR $\left(\mathrm{CD}_{3} \mathrm{OD}\right)$ and HSQC spectrum of 1 contained 11 carbon signals corresponding to two methyls at $\delta_{\mathrm{C}} 16.8(\mathrm{C}-1)$ and $17.00(\mathrm{C}-9)$; six methines at $\delta_{\mathrm{C}} 50.7(\mathrm{C}-4), 126.2(\mathrm{C}-2), 126.9(\mathrm{C}-7), 129.2$ (C-6), 129.6 (C-8), and 130.7 (C-3); and two methylenes at $\delta_{\mathrm{C}} 58.1(\mathrm{C}-10)$ and $64.4(\mathrm{C}-11)$. The COSY spectrum (Fig. 1) revealed contiguous protons of $\mathrm{H}-9 / \mathrm{H}-8 / \mathrm{H}-7 / \mathrm{H}-6$ and $\mathrm{H}-1 / \mathrm{H}-2 / \mathrm{H}-3 / \mathrm{H}-4 / \mathrm{H}-11$. Key cross-peaks of HMBC spectrum (Fig. 1) including $\delta_{\mathrm{H}} 4.18\left(\mathrm{H}_{2}-10\right) / \delta_{\mathrm{C}} 137.6$ $(\mathrm{C}-5)$, 50.4 (C-4), and $129.2(\mathrm{C}-6) ; \delta_{\mathrm{H}} 3.63\left(\mathrm{H}_{2}-11\right) / \delta_{\mathrm{C}}$ $137.6(\mathrm{C}-5), 50.4(\mathrm{C}-4)$, and $130.7(\mathrm{C}-3) ; \delta_{\mathrm{H}} 3.00(\mathrm{H}-4) /$ $\delta_{\mathrm{C}} 130.7(\mathrm{C}-3), 137.6(\mathrm{C}-5), 129.2(\mathrm{C}-6)$, and $126.2(\mathrm{C}-2)$ were observed. The structure of $\mathbf{1}$ was thus determined as shown in Fig. 2, and named nigaurdiol. The chemical skeleton of $\mathbf{1}$ has not been reported previously; it could be a recemate since the optical rorational value of $\mathbf{1}$ was close to zero.

All six isolates were evaluated for their inhibitory effects on nitric oxide (NO) production and cytotoxicity in LPS-activated microglial BV-2 cells. For positive control, curcumin was used with an $\mathrm{IC}_{50}$ value of $6.0 \pm 0.3 \mu \mathrm{M}$. Compounds 3, 4, and 6 showed potently inhibitory effects with $\mathrm{IC}_{50}$ value of $2.3 \pm 0.3,2.5 \pm 0.5$, and 7.2 \pm 1.4 , respectively; however, compounds 3 and $\mathbf{4}$ exhibited significant cytotoxicity against microglial BV-2 cell with viabillities of $10.7 \pm 0.8$ and $11.3 \pm 1.3 \%(10 \mu \mathrm{M})$,

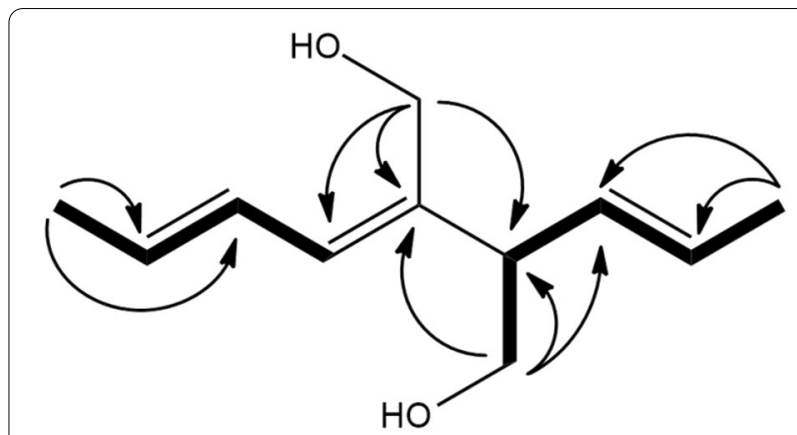

COSY:

HMBC:

Fig. 1 Key HMBC and COSY correlations for compound $\mathbf{1}$

respectively. Furthermore, compound $\mathbf{6}$ showed no significant cytotoxic effect with the survival of cells at concentration $10 \mu \mathrm{M}$ of $90.8 \pm 6.7 \%$. Compounds $\mathbf{1}, 2$ and 5 showed weak inhibitory effects and no cytotoxic activity (Table 1). Ergosterol (6) is the major sterol endogenously produced by fungi and protozoa with diverse bioactivities-including anti-inflammatory, anti-cancer, and immune-modulatory effects (Lee et al. 2017; Papoutsis et al. 2020).

\section{Conclusions}

In this report, we have identified one new compound, nigaurdiol (1), along with five known compounds $2-6$ from an endophytic fungus (identified as Nigrospora aurantiaca "TMU062) associated with Melaleuca leucadendra Linn. Of the compounds identified, the chemical skeleton of nigaurdiol (1) is being shown for the first time. All compounds were evaluated by in-vitro NO inhibitory assay in the LPS-stimulated murine BV-2 microglial cell line. The results showed potential inhibitory activities in bostrycin (3), deoxybostrycin (4), and ergosterol (6) than nigaurdiol (1), xyloketal K (2), and xylanthraquinone (5) weak inhibitory activities. Bostrycin (3) and deoxybostrycin (4) exhibited significant cytotoxicity against microglial BV-2 cell.

\section{Methods}

\section{General experimental procedures}

${ }^{1} \mathrm{H},{ }^{13} \mathrm{C}$, DEPT, and 2D NMR were acquired on Agilent DD2 $600 \mathrm{MHz}$ pectrometer (Agilent Technologies, Santa Clara, CA, USA). Optical rotation was measured with a JASCO P-2000 polarimeter (Tokyo, Japan). IR spectra were recorded on a JASCO FT/IR 4100 spectrometer (Tokyo, Japan). Sephadex LH-20 (GE Healthcare, Uppsala, Sweden) was used for open column chromatography. High-resolution mass spectrometry data was acquired using Q Exactive Plus Hybrid 
<smiles>C/C=C/C=C(CO)C(/C=C/I)CO</smiles><smiles>Cc1cc(O)c2c(c1)O[C@]1(C)OC[C@H](C)C1C2</smiles><smiles>COC1=CC(=O)c2c(O)c3c(c(O)c2C1=O)C[C@@](C)(O)[C@H](O)[C@H]3O</smiles><smiles>COC1=CC(=O)c2c(O)c3c(c(O)c2C1=O)C[C@@](C)(O)[C@H](O)C3</smiles><smiles>COc1cc(O)c2c(c1O)[C@H](O)[C@@H]1C[C@](C)(O)[C@@H](O)C[C@H]1C2=O</smiles><smiles>CC(C)[C@H](C)/C=C/[C@H](C)C1CCC2C3=CC=C4C[C@@H](O)CC[C@]4(C)C3CC[C@]21C</smiles>

Fig. 2 Chemical structures of compounds 1-6

Table $1 \mid C_{50}$ and cell viabillity values of compounds in BV-2 microgial cells

\begin{tabular}{lcl}
\hline Compounds & $\mathbf{I C}_{\mathbf{5 0}}(\boldsymbol{\mu M})$ & Cell viabillity (\%) \\
\hline 1 & $32.2 \pm 3.3$ & $102.6 \pm 8.8$ \\
2 & $30.1 \pm 3.0^{*}$ & $98.3 \pm 7.6$ \\
3 & $2.3 \pm 0.3^{* * *}$ & $10.7 \pm 0.8^{* * *}$ \\
4 & $2.5 \pm 0.5^{* * *}$ & $11.3 \pm 1.3^{* * *}$ \\
5 & $32.1 \pm 6.7$ & $102.8 \pm 6.9$ \\
6 & $7.2 \pm 1.4^{* * *}$ & $90.8 \pm 6.7$ \\
$R$ & $1.4 \pm 0.8$ & $100.0 \pm 0$ \\
$V$ & $38.2 \pm 4.7^{\# \# \#}$ & - \\
Curcumin & $6.0 \pm 0.3$ & - \\
\hline
\end{tabular}

Data are as the mean $\pm \mathrm{SD}(n=3)$

${ }^{*} p<0.05,{ }^{* *} p<0.01$, and ${ }^{* * *} p<0.001$ compared with the stimulation (V); $\# \# \#<0.001$ compared with the resting (R)

Quadrupole-Orbitrap Mass Spectrometer (Thermo Fisher Scientific, Bremen, Germany) coupled with the Dionex UltiMate $^{\mathrm{TM}} 3000$ RSLCnano UHPLC system (Thermo Fisher Scientific, San Jose, CA, USA). Semipreparative HPLC experiments for compound purification were performed using HPLC pump L-7100 (Hitachi, Japan) with refractiveindex (Bischoff, Leonberg, Germany) for detector.

\section{Fungal material}

The fungal strain Nigrospora aurantiaca was isolated from a healthy leaf of Melaleuca leucadendra linn collected in the yard of National Taiwan University and was identified by sequencing the internal transcribed spacer regions of the rDNA (ITS). A BLAST search of the sequence led to the best match of Nigrospora aurantiaca. Mycelium Nigrospora aurantiaca ${ }^{\#}$ TMU062 was inoculated into two different media-liquid medium and solid medium. Inoculation in liquid medium was done in $5 \mathrm{~L}$ serum bottles, each containing $50 \mathrm{~g}$ of malt extract (Becton, Dickinson and Company, Sparks, USA) and 3.5 L of deionized water. The fermentation was conducted with aeration at $25-30{ }^{\circ} \mathrm{C}$ for 14 days. As for solid medium, $250 \mathrm{~mL}$ flasks were used-each containing $20 \mathrm{~g}$ of barley and $0.2 \mathrm{~g}$ of potato dextrose agar (Becton, Dickinson and Company, Sparks, USA). After adding $15 \mathrm{~mL}$ of deionized water, they were fermented for 30 days at $27-30^{\circ} \mathrm{C}$.

\section{Extraction and isolation}

The fermented broth $(9.5 \mathrm{~L})$ was filtered and partitioned five times with equal volumes of EtOAc and subsequently concentrated in vacuum to obtain crude extract $(5.8 \mathrm{~g})$. The crude extract was re-dissolved in $50 \mathrm{~mL} \mathrm{MeOH}$ to obtain $\mathrm{MeOH}$ layer and sediment $(2.3 \mathrm{~g})$. Then, the sediment was dissolved in $10 \mathrm{~mL}$ DMSO and purified by HPLC semipreparative reversed-phase column 
(Phenomenex Luna PFP, $5 \mu \mathrm{m}, 10 \times 250 \mathrm{~mm}$, Torrance, CA, USA) eluted by $65 \% \mathrm{MeOH}, 2 \mathrm{~mL} / \mathrm{min}$, to obtain 3 $\left(t_{\mathrm{R}}: 12 \mathrm{~min} ; 50.0 \mathrm{mg}\right)$ and three fractions (Fr.S2-Fr.S4). Further purification of Fr.S3 on HPLC on a semipreparative reversed-phase column (Thermo Hypersil HS C18, $5 \mu \mathrm{m}, 10 \times 250 \mathrm{~mm}$, Bellefonte, PA, USA) eluted by $50 \% \mathrm{MeOH}, 2 \mathrm{~mL} / \mathrm{min}$ to obtain $4\left(t_{\mathrm{R}}: 9 \mathrm{~min} ; 4.9 \mathrm{mg}\right)$. The $\mathrm{MeOH}$ layer was concentrated under vacuum into $15 \mathrm{~mL}$, then applied into a Sephadex LH-20 column $(2.5$ i.d. $\times 68.5 \mathrm{~cm})$ eluted by $\mathrm{MeOH}$ with a flow rate of $2.5 \mathrm{~mL} / \mathrm{min}$ to give forty-five fractions $(25 \mathrm{~mL})$ before combined into seven fractions as Fr.A - Fr.G based on similar compositions of TLC analysis. The Fr.B (1.3 g) and Fr.C (1.05 g) were purified by HPLC on a semipreparative reversed-phase column (Phenomenex Luna PFP, $5 \mu \mathrm{m}$, 10 i.d. $\times 250 \mathrm{~mm}$, Torrance, CA, USA) eluted by $\mathrm{MeOH}$ (respectively, 60\% and 65\%) to obtain four subractions (Fr. B1-Fr.B4) and eight subfractions (Fr.C1-Fr.C8) from Fr.B dan Fr.C, respectively. Further purification of Fr.B1 and Fr.C7 by HPLC semipreparative reversed-phase column (Thermo Hypersil HS C18, $5 \mu \mathrm{m}, 10$ i.d. $\times 250 \mathrm{~mm}$, Bellefonte, PA, USA) eluted by $\mathrm{MeOH}_{\mathrm{aq}}$ (respectively, $30 \%$ and $50 \%)$ to give 1 ( $\left.t_{\mathrm{R}}: 21 \mathrm{~min} ; 3.2 \mathrm{mg}\right), 2\left(t_{\mathrm{R}}: 25 \mathrm{~min} ; 3.5 \mathrm{mg}\right)$ and $5\left(t_{\mathrm{R}}: 13 \mathrm{~min}, 7.0 \mathrm{mg}\right)$. The solid fermented products were grinded into a powder after cryodesiccation and than extracted four times with $\mathrm{MeOH}$ (equal volumes). The crude extracts were suspended with $\mathrm{H}_{2} \mathrm{O}$ and partitioned three times with EA, $n$-hexane, and $n$-butanol, respectively (equal volumes). The dried $n$-hexane extract $(3.4 \mathrm{~g})$ was subjected to gravity column chromatography (5 i.d. $\times 17 \mathrm{~cm}$ ) with silica, eluted with $n$-hexane, EA, and $\mathrm{MeOH}$ by gradient system to yield 52 fractions, beofre combined into 12 fractions (fr.A-Fr.L) based on similar compositions of TLC analysis. Compound $6(10.0 \mathrm{mg})$ was obtained from the recrystallization of fraction Fr.B at $-4{ }^{\circ} \mathrm{C}$ for $12 \mathrm{~h}$.

\section{Nigaurdiol (1)}

colorless oil; $[\alpha]^{25}{ }_{\mathrm{D}}=-1.2(c \quad 0.3, \mathrm{MeOH}) ; \mathrm{IR}\left(v_{\max }\right.$, $\mathrm{KBr})$ : at 3334 and $1646 \mathrm{~cm}^{-1}$; HR-ESI-MS: $[\mathrm{M}+\mathrm{H}]^{+}$ $m / z 183.1381$ (calcd. 183.1380 for $\mathrm{C}_{11} \mathrm{H}_{19} \mathrm{O}_{2}$ ); ${ }^{1} \mathrm{H}$ and ${ }^{13} \mathrm{C}$ NMR see Table 2.

\section{Microglial culture}

The murine BV-2 microglial cell line cultured followed the procedure of our previous reports (Hsiao et al. 2020). In summary, BV- 2 cells were cultured with DMEM containing Fetal Bovine Serum (FBS), streptomycin/penicillin, Lglutamine and HEPES at $37{ }^{\circ} \mathrm{C}$, humidified $5 \% \mathrm{CO}_{2}$. Prior to the study, BV-2 cells were cultured in FBS media (5\%), pretreated with carrier media or various concentrations of compounds for $15 \mathrm{~min}$, and eventually collected after $24 \mathrm{~h}$ of stimulation with LPS (150 $\mathrm{ng} / \mathrm{mL})$.
Table 2 NMR data of compound 1 in $\mathrm{CD}_{3} \mathrm{OD}$

\begin{tabular}{lrl}
\hline Position & \multicolumn{1}{c}{$\boldsymbol{\delta}_{\mathbf{C}}$} & $\boldsymbol{\delta}_{\mathbf{H}}(\boldsymbol{J}$ in $\mathbf{H z})$ \\
\hline 1 & 16.8 & $1.67(\mathrm{~d}, 3 \mathrm{H}, J=6.2 \mathrm{~Hz})$ \\
2 & 126.2 & $5.52(\mathrm{dq}, 1 \mathrm{H}, J=16.4,6.2 \mathrm{~Hz})$ \\
3 & 130.7 & $5.43(\mathrm{dd}, 1 \mathrm{H}, J=16.4,7.0 \mathrm{~Hz})$ \\
4 & 50.4 & $3.00(\mathrm{dt}, 1 \mathrm{H}, J=7.0,7.0 \mathrm{~Hz})$ \\
5 & 137.6 & \\
6 & 129.2 & $5.94(\mathrm{~d}, 1 \mathrm{H}, J=11.0 \mathrm{~Hz})$ \\
7 & 126.9 & $6.43(\mathrm{ddq}, 1 \mathrm{H}, J=14.8,11.0,1.2 \mathrm{~Hz})$ \\
8 & 129.6 & $5.70(\mathrm{dq}, 1 \mathrm{H}, J=14.8,6.7 \mathrm{~Hz})$ \\
9 & 17.0 & $1.77(\mathrm{dd}, 3 \mathrm{H}, J=6.7,1.2 \mathrm{~Hz})$ \\
$10 \mathrm{a}$ & 58.1 & $4.18(\mathrm{~d}, 1 \mathrm{H}, J=12.0 \mathrm{~Hz})$ \\
$10 \mathrm{~b}$ & & $4.14(\mathrm{~d}, 1 \mathrm{H}, J=12.0 \mathrm{~Hz})$ \\
$11 \mathrm{a}$ & 64.4 & $3.63(\mathrm{dd}, 1 \mathrm{H}, J=10.7,7.0 \mathrm{~Hz})$ \\
$11 \mathrm{~b}$ & & $3.55(\mathrm{dd}, 1 \mathrm{H}, J=10.7,7.0 \mathrm{~Hz})$ \\
\hline
\end{tabular}

\section{Cell viability assays}

As in our previous report, cellular viability was assessed using MTT test where BV-2 cells, along with other compounds were treated for $24 \mathrm{~h}$ (Hsiao et al. 2020).

\section{Detection of nitric oxide production}

The level of nitric oxide (NO) metabolites from the production of activated BV-2 cells was measured with reference to the Griess method (Wang et al. 2018).

\section{Acknowledgements}

We are grateful to Chia-Wei Ku for the NMR data acquisition at the TMU Core Facility and Shu-Yun Sun of the College of Science Instrumentation Center of National Taiwan University for the MS data acquisition.

\section{Authors' contributions}

SS performed the experiments and drafted the initial manuscript. GH measured the biological activity data. T-HL assisted with the data curation, supervision, and methodology. C-KL performed the conceptualization and funding acquisition. All authors have read and approved the final manuscript.

\section{Funding}

This research was funded by the Ministry of Science and Technology of ROC for financial supports (MOST107-2320-B-038-019-MY3).

\section{Declarations}

\section{Competing interests}

The authors declare that they have no known competing finansial interests or personal relationships that could have influenced the work reported in this paper.

\section{Author details}

${ }^{1}$ Clinical Drug Development of Herbal Medicine, College of Pharmacy, Taipei Medical University, Taipei 11031, Taiwan. ${ }^{2}$ Department of Pharmacy, Faculty of Health Science, University of Muhammadiyah Mataram, Mataram 83127, Indonesia. ${ }^{3}$ Graduate Institute of Medical Sciences, College of Medicine, Taipei Medical University, Taipei 11031, Taiwan. ${ }^{4}$ Department of Pharmacology, School of Medicine, Taipei Medical University, Taipei 11031, Taiwan. ${ }^{5}$ Institute of Fisheries Science, National Taiwan University, Taipei 10617, Taiwan. ${ }^{6}$ School of Pharmacy, Taipei Medical University, Taipei 11031, Taiwan. 
Received: 6 June 2021 Accepted: 21 September 2021

Published online: 26 October 2021

\section{References}

Chen $\mathrm{H}$, Zhong L, Long $Y$ et al (2012) Studies on the synthesis of derivatives of marine-derived bostrycin and their structure-activity relationship against tumor cells. Mar Drugs 10:932-952

Cui Y, Yi D, Bai X et al (2012) Ginkgolide B produced endophytic fungus (Fusarium oxysporum) isolated from Ginkgo biloba. Fitoterapia 83:913-920

Hardoim PR, van Overbeek LS, Berg G et al (2015) The hidden world within plants: ecological and evolutionary considerations for defining functioning of microbial endophytes. Microbiol Mol Biol Rev 79:293-320

Hsiao G, Wang S-W, Chiang Y-R et al (2020) Anti-inflammatory effects of peptides from a marine algicolous fungus Acremonium sp. NTU492 in BV-2 microglial cells. J Food Drug Anal 28:283-291

Kawai J, Higuchi Y, Hirota M et al (2018) Ergosterol and its derivatives from Grifola frondosa inhibit antigen-induced degranulation of RBL-2H3 cells by suppressing the aggregation of high affinity lgE receptors. Biosci Biotechnol Biochem 82:1803-1811

Keszei A, Brubaker CL, Foley WJ et al (2008) A molecular perspective on terpene variation in Australian Myrtaceae. Aust J Bot 56:197-213

Kumari M, Taritla S, Sharma A, Jayabaskaran C (2018) Antiproliferative and antioxidative bioactive compounds in extracts of marine-derived endophytic fungus Talaromyces purpureogenus. Front Microbiol 9:1777-1789

Lee C, Kim S, Li W et al (2017) Bioactive secondary metabolites produced by an endophytic fungus Gaeumannomyces sp. JS0464 from a maritime halophyte Phragmites communis. J Antibiot (Tokyo) 70:737-742

Monzote L, Scherbakov AM, Scull R et al (2020) Essential oil from Melaleuca leucadendra: antimicrobial, antikinetoplastid, antiproliferative and cytotoxic assessment. Molecules 25:5514
Papoutsis K, Grasso S, Menon A et al (2020) Recovery of ergosterol and vitamin D2 from mushroom waste-potential valorization by food and pharmaceutical industries. Trends Food Sci Technol 99:351-366

Pujiarti R, Ohtani Y, Ichiura H (2011) Physicochemical properties and chemical compositions of Melaleuca leucadendron leaf oils taken from the plantations in Java, Indonesia. J Wood Sci 57:446-451

Rini P, Ohtani Y, Ichiura H, Pujiarti R (2012) Chemical compositions, antioxidant and antifungal activities of Melaleuca leucadendron Linn. Leaf oils from Indonesia. Wood Res J 3:23-29

Sommart U, Rukachaisirikul V, Sukpondma Y et al (2008) Hydronaphthalenones and a dihydroramulosin from the endophytic fungus PSU-N24. Chem Pharm Bull (Tokyo) 56:1687-1690

Stevens KL, Badar-Ud-Din AA, Ahmad M (1979) The antibiotic bostrycin from Alternaria eichhorniae. Phytochemistry 18:1579-1580

Sun Z-H, Liang F-L, Chen Y-C et al (2016) Two new xyloketals from the endophytic fungus Endomelanconiopsis endophytica derived from medicinal plant Ficus hirta. J Asian Nat Prod Res 18:1036-1041

Ukwatta KM, Lawrence JL, Wijayarathne CD (2020) Antimicrobial, anti-cancer, anti-filarial and anti-inflammatory activities of Cowabenzophenone A extracted from the endophytic fungus Aspergillus terreus isolated from a mangrove plant Bruguiera gymnorrhyza. Mycology 11:297-305

Wang C, Wang J, Huang Y et al (2013) Anti-Mycobacterial activity of marine fungus-derived 4-deoxybostrycin and nigrosporin. Molecules 18:1728-1740

Wang S, Suh JH, Hung W-L et al (2018) Use of UHPLC-TripleQ with synthetic standards to profile anti-inflammatory hydroxycinnamic acid amides in root barks and leaves of Lycium barbarum. J Food Drug Anal 26:572-582

\section{Publisher's Note}

Springer Nature remains neutral with regard to jurisdictional claims in published maps and institutional affiliations.

\section{Submit your manuscript to a SpringerOpen ${ }^{\circ}$ journal and benefit from:}

- Convenient online submission

- Rigorous peer review

- Open access: articles freely available online

- High visibility within the field

- Retaining the copyright to your article

Submit your next manuscript at $\boldsymbol{\nabla}$ springeropen.com 